\title{
Organizational management through strategic planning and financial practices: An empirical assessment from business firms of Kuwait
}

\author{
Ahmed Nahar Al Hussaini ${ }^{a^{*}}$
}

${ }^{a}$ The Public Authority for Applied Education \& Training, The College of Business Studies, State of Kuwait

\begin{tabular}{l}
\hline C H R O N I C L E \\
\hline Article history: \\
Received: December 16, 2018 \\
Received in revised format: Feb- \\
ruary 1, 2019 \\
Accepted: February 6, 2019 \\
Available online: \\
February 6, 2019 \\
\hline Keywords: \\
Strategic planning \\
Financial management \\
Model specification \\
Traditional linear regression \\
Kuwait
\end{tabular}

\section{Introduction}

From the context of business management, strategic planning has prodigious attention in the literature (Sayer et al., 2011). It is assumed that strategic planning (SP) is associated with those decisions having longer impact on all the activities of the business and they are normally irreversible (Camillus \& Datta, 1991; Goodstein et al., 1986; Grant, 2003; King, 1983). Long-run tactical planning like SP deals with all types of business decisions within and outside the business world (Steiner, 2010). It encompasses that business decisions have longer impacts on all activities, with their division in short run objectives. For the future growth of business organization, strategic planning uses all types of resources, either measured in financial terms or not (Carr \& Smeltzer, 2000). As per the earlier findings, SP employs overall business purposes, its future orientation. Dealing with those factors in return can impact business in the future (Cassidy, 2016; Haines, 2016; Harrison, 1995; Wolf \& Floyd, 2017; Anigbogu \& Nduka, 2014). From 1980 to 1990, SP covered new trends as means of focusing on rapid changes in the business environment with effective decisions for the success (Carter, 1999; Haines, 2016; Kemp,

\footnotetext{
* Corresponding author.

E-mail address: drahmednahar@gmail.com (A. N. Al Hussaini)

(C) 2019 by the authors; licensee Growing Science, Canada doi: $10.5267 / \mathrm{j} . \mathrm{msl} .2019 .2 .001$
} 
2018; Anyanwu et al., 2016). This concept has been widely applied in the retail industry where successful planning yields a reasonable output. Meanwhile, SP entitles as significant managerial process for the effective planning. For instance, in hotel industry, strategic planning as core business management element is explained through SP index which considers six factors. These are under the title of implementation of planning, performance in future, historical trends of company progress, functional coverage, dependence on analytical techniques, and accessing the planning for the assistance of staff (McLean, 2018; Phillips \& Moutinho, 1999; Tikhomirov \& Frenkel, 2017). In addition, the context of literature while "simplifying strategic planning" explains various alternatives which can save time in developing a business plan, making it easier for the implementation and focus on more significant issues (Sokol, 1992). Using quality function deployment (QFD), strategic planning for the business can be developed (Crowe \& Cheng, 1996; Kahraman et al., 2006; Killen et al., 2005).

In addition, financial management practices (FMPs) cover vast bodies of literature. Several business organizations, either financial or non-financial, deal with financial matters as identified by the earlier researchers (Cordón-Pozo et al., 2006; Cuijpers et al., 2011). Various factors play their role in affecting the departmental collaboration (Quinlan \& Åkerlind, 2000; Maldonado-Guzman et al., 2018). From the context of corporate finance, accounting and finance departments are known as the core heads, responsible for the overall financial affairs in the business. The objective of the present study is to evaluate the impact of various dimensions of strategic planning on financial management practices in business firms of Kuwait. Based on this phenomenon, the present study is contributing to the existing literature with the integration of strategic planning and its relationship with financial dimensions. The rest of the paper is as follows. Section two elaborates literature review. Section three indicates variables and methods. Sections four and five explain findings and their discussion, and the last section explains conclusions, limitations and future directions.

\section{Literature Review of the Study}

Business management through strategic planning has received significant attention since the 1990s. Strategic planning indicates a mean for monitoring rapid changes in the business environment and reacting against that situation. In his study, Carter (1999) explained that effective decision making is an integral component in the overall management process and explains the core elements of the successful planning. Meanwhile, planning horizon in the business firm considers those boundaries, deciding the future direction with the time (Das, 1991). He also explains the planning horizons with the concept of temporal framework as time plays its significant role and support. Some other studies convey the idea that strategic planning covers those decisions, having future implications and long-term effects on operational activities of the business (Camillus \& Datta, 1991; King, 1983; King \& Cleland, 1978). In addition, few researchers have focused on quality function deployment for the strategic planning and explain that it is a comprehensive process, covering the various issues, faced by the organization for its stakeholders. Their study design consists of two core stages of SP with the help of QFD (Chan \& Wu, 2002; Crowe \& Cheng, 1996; Kahraman et al., 2006; Killen et al., 2005; Tan \& Shen, 2000; Tsai et al., 2003; Maroofi et al., 2017; Mowlaei, 2017; Santhi \& Gurunathan, 2014). Findings show significant benefit through QFD and are the supporting outcome of developed strategies within the business firms. Practical implications imply that QFD model is very useful for the development of customer related strategy. Meanwhile, strategic planning and planning strategically are both inter-related ideas covering lengthy process of decision making (Linn, 2008). He explains that organization should not go for the intricate strategic planning process because it is a laborious process.

Financial management practices cover the title for all types of financial decisions in the business and relevant resources. For example, Rashid (2014) specifies that external financing decision of the firm is dealing with the risk factor through idiosyncratic and macroeconomic dimensions. His study covers the role of both type of risk factors through equity choices while using the panel data from 1981 to 2009. Findings of the study explains that both risk factors are significantly impacting on external financing choices in the region of Pakistan. As per the practical implications, his study is useful for the corporate 
financial practices especially relevant to external financing decisions, based on macroeconomic factors. Research work of Ali and Mehreen (2018) empirically explores the impact of succession planning for combating the employee turnover. They explained the fact that leader's development process is associated with the performance and retention of employees. The focus of their study was on banking professionals. They further narrated that success planning enhances the job security for the employees while creating more opportunities for them. The study uses the survey approach in retail banking through proposed model and structural relationship. As per the practical implications, their work helps the banking sector management develop proactive and strategic planning related to employee job security. Some other studies (e.g. Brooks \& Mukherjee, 2013; Charnes et al., 1959; Dayananda et al., 2002; Froot \& Stein, 1998; Kaka, 1994) consider financial budget as financial practices in the business firms, while security of financial and physical assets is another indicator for the dimension of financial practices (Ali \& Haseeb, 2019; Haseeb et al., 2018; Suryanto et al., 2018; Malarvizhi et al., 2018).

\section{Methodology}

\subsection{Variables of the study}

\subsubsection{Strategic planning}

Strategic planning refers to long-term planning in the business to achieve the objectives over time (Dansoh, 2005; Grant, 2016; Kaplan \& Norton, 1996; Mcdonald, 2016; Slawinski \& Bansal, 2015). Various factors have been discussed in the literature to cover the idea of strategic planning as business management indicators. Strategic planning composes business mission and its meaningfulness to everyone within the organization (Klemm et al., 1991), and the contribution of SP in business (Bryson et al., 2009). Through strategic planning, businesses can maximize the market opportunities (Utterback, 1994), motivation of staff up to appropriate level through reward system, working as a team (Fisher, 2009; Lam \& Lambermont-Ford, 2010) and safety of operational plans (Howlett, 2009; Sayer et al., 2011). Besides, profitability targets are met through strategic planning (Kaplan \& Norton, 2001; Midler, 2013; Ruhanen, 2007), products meeting all the requirements of the market place, and revisiting innovation plans of the products and meeting the safety laws for the employees are under the title of strategic planning (Enz \& Siguaw, 2003; Hopkins, 1981; Reese, 2008; Callaway, 2017).

\subsubsection{Financial Practices}

Financial practices in the business firms explain numerous factors covering both short term and long term impact. Among the various, external financing opportunities is the availability of the funds to the business from outside resources (Abor \& Biekpe, 2007; Berger \& Udell, 2002; Mayer, 1988; Stein, 1997), and adequate staffing of financial staff (Abor \& Biekpe, 2007). While turnover of employees from accounting and finance department indicates that business practices have financial impact in the business (Guilding et al., 2014), development of financial budgets (Agarwalla et al., 2015; Alviniussen \& Jankensgard, 2015; Dudin et al., 2015; Purnama, 2014) and protection of business assets with relevant strategies are some other practices relevant to the organization (Main, 2016). All these items are under consideration in present study.

This study focusses on the structural questionnaire approach from targeted respondents (employees), working in business firms in Kuwait. A sample of 350 questionnaires was proposed and distributed to various employees specifically responsible for the strategic planning and financial practices in their relevant firms. A period of 3 weeks was proposed to collect the delivered questionnaires. A final sample of 276 questionnaires was collected with no missing observations, covering all the responses from targeted respondents. After the collection of relevant data from targeted respondents in the industry, descriptive statistics were applied in the very first step. The key purpose to apply the descriptive technique was to evaluate the data set. In the second step, the model specification test was applied, referring to the goodness of relationship between the strategic planning and key dimensions of financial practices. In the last step, empirical results were generated through traditional regression modelling. 


\section{Results and Discussion}

Descriptive results are presented under the first table of the study. To evaluate the layout of the data set, mean score, standard deviation, minimum \& maximum scores are presented in Table 1. In addition, first percentile and $99^{\text {th }}$ percentile along with skewness and kurtosis are also demonstrated. For business management, strategic planning is observed as an independent variable of the study, based on fifteen items, ranging from BMSP1 to BMSP15. For financial management five items are added from existing literature. To get descriptive facts, SPSS-22 versions has been applied. For BMSP1, mean score of 4.438 indicates that on average, respondents agreed on the Likert scale, ranging from 1 to 5 (strongly disagree to strongly agree) with the argument that business mission is quite significant for all the individuals within the organization (BMSP1). Standard deviation for this average response is 1.272, assuming a reasonable aberration from the mean value. Range of response is 1 to 5 with positive skewed .311 , while score for the Kurtosis is 2.001. For BMSP2, mean score is 4.108 indicating an agreed view from respondents, which demonstrates that strategic planning of the company is positively contributing towards mission; BMSP2. BMSP3 presumes the fact that business firms are maximizing their opportunities when they arise. However, as per the descriptive facts, respondents are somehow on the neutral scale as the mean value is 3.92. While the trend of data as identified through skewness is positive for second proxy of business management and negative for the third. For BMSP4, neutral response is observed with the mean value of 2.903 and standard deviation of 1.372. It indicates that when the staff members are asked about their motivation and get involved in their roles, they remained neutral in the strategic planning process. This trend puts significant light towards attracting the business attention about employees' motivation and their involvement in the business. Fifth dimension of business management generally and specifically deals with strategic planning and is associated with jobs accomplished by the employees with appropriate level. As per descriptive facts, respondents agreed with the argument that they were doing their job within a reasonable level. BMSP6 considers "staff feelings very well about the reward and recognition within the organization" with average response of 4.67 approximately. It indicates respondents are largely agreed about reward and recognition system within the organization.

In addition, strategic planning also takes the idea of working as a team and BMSP7 is addressing the statement that staff in the business firm is working as a crew to achieve the strategic objectives. Mean score for this statement is 3.092, indicating a neutral argument from the respondents. It implies that attention is required to get the proper feedback from the employees as they remain neutral in this regard. The eighth factor of strategic planning entitles that metrics were defined in the company, matching the strategic planning. It covers the average score of 1.94 which explains that respondents disagreed for the definition of metrics in the business. This idea elucidates that there was a strong need of metrics in the targeted business firms, which will help them in strategic planning. For BMSP9, focus is paid towards metrics, required to operate effectively. As it is linked with BMSP8, again respondents disagree on the Likert scale with the average score of 1.182, while customers served with significant attention were under observation in strategic planning covers BMSP10. It indicates that employees of selected firms strongly agree with the assumption that their organization was focusing on customer services while developing strategic planning. Items under the title of BMSP11 and 12 cover the operational safety of the plans being developed and achievements of profitability targets. Both items have a mean score of above 4, meaning that respondents agreed with the achievements of financial targets and operational safety of the plans being developed. Besides, "products are meeting the market needs" is evaluated under the title of BMSP13, while revisiting of the innovation plan is covered through BMSP14. For both factors, respondents agreed that management was focusing on these issues. Meeting health and safety criteria is entitled for BMSP15 with mean value of 2.013, explaining that employees disagreed about the business focus on HR practices through employees' safety and health.

The factors under the title of FM1 to FM5 predict various factors of financial management, covering the external financing of business projects or FM1, adequate staffing of financial staff FM2, turnover 
rate of accounting and finance personnel (FM3), development of financial budgets (FM4), proper policies for safeguarding physical and financial assets in the business (FM5). All these items for FM show a mean score near to Likert point of four, predicting that targeted respondents agree for all these financial practices, except FM3 with the average score of 2.23 assuming a neutral feedback.

\section{Table 1}

Descriptive Statistics

\begin{tabular}{llllrrrrrr}
\hline Variables & Obs & Mean & SD & Min & Max & p1 & p99 & Skew. & Kurt. \\
\hline BMSP1 & 276 & 4.438 & 1.272 & 1 & 5 & 1 & 5 & .311 & 2.001 \\
BMSP2 & 276 & 4.108 & 1.272 & 1 & 5 & 1 & 5 & .086 & 1.958 \\
BMSP3 & 276 & 3.926 & 1.161 & 1 & 5 & 1 & 5 & -.141 & 2.091 \\
BMSP4 & 276 & 2.903 & 1.372 & 1 & 5 & 1 & 5 & .041 & 1.726 \\
BMSP5 & 276 & 4.017 & 1.379 & 1 & 5 & 1 & 5 & -.057 & 1.712 \\
BMSP6 & 276 & 4.676 & 1.266 & 1 & 5 & 1 & 5 & -.662 & 2.327 \\
BMSP7 & 276 & 3.091 & 1.312 & 1 & 5 & 1 & 5 & -.107 & 1.899 \\
BMSP8 & 276 & 1.943 & 1.359 & 1 & 5 & 1 & 5 & -.076 & 1.839 \\
BMSP9 & 276 & 1.182 & 1.236 & 1 & 5 & 1 & 5 & -.333 & 2.107 \\
BMSP10 & 276 & 4.955 & 1.368 & 1 & 5 & 1 & 5 & .028 & 1.755 \\
BMSP11 & 276 & 4.375 & 1.246 & 1 & 5 & 1 & 5 & -.451 & 2.274 \\
BMSP12 & 276 & 4.415 & 1.138 & 1 & 5 & 1 & 5 & -.348 & 2.462 \\
BMSP13 & 276 & 4.637 & 1.404 & 1 & 5 & 1 & 5 & .239 & 1.795 \\
BMSP14 & 276 & 4.074 & 1.301 & 1 & 5 & 1 & 5 & -.552 & 1.972 \\
BMSP15 & 276 & 2.013 & 1.259 & 1 & 5 & 1 & 5 & -.316 & 2.046 \\
FM1 & 276 & 4.307 & 1.259 & 1 & 5 & 1 & 5 & -.265 & 2.024 \\
FM2 & 276 & 4.517 & 1.289 & 1 & 5 & 1 & 5 & .256 & 1.993 \\
FM3 & 276 & 2.233 & 1.245 & 1 & 5 & 1 & 5 & .305 & 2.178 \\
FM4 & 276 & 4.244 & 1.318 & 1 & 5 & 1 & 5 & -.336 & 2.003 \\
FM5 & 276 & 3.898 & 1.336 & 1 & 5 & 1 & 5 & .531 & 1.915 \\
\hline
\end{tabular}

Table 2 presumes correlational coefficients among all the items of strategic planning for business management. Correlation between BMSP1 and BMSP2 is positively moderate and significant at five percent. Similar positive and significant trend is found between first and third item, between first and fourth item between first and sixth item, between first and seventh item, between first and $10^{\text {th }}$ item of business management. While for BMSP2, the highest correlation is examined with BMSP10. As per BMSP3, correlation is .351, significant at 5 percent with BMSP4 and with BMSP14 is .431. The rest of the indicators are showing a mixed trend but most of the correlation coefficients are found to be significantly positive. To address the queries for the problem of multicollinearity, VIF test is applied, measuring the tolerance and mean value of the tolerance for correlation. Table 3 presents individual correlation and mean value of tolerance under the title of Mean VIF. It is observed that all the items of strategic planning for business management had a mean score of below 2, and overall mean VIF is 1.386. As per the findings of earlier researchers, mean VIF less than five can be assumed as enough evidence to conclude that explanatory variables had no problematic level of correlation. 


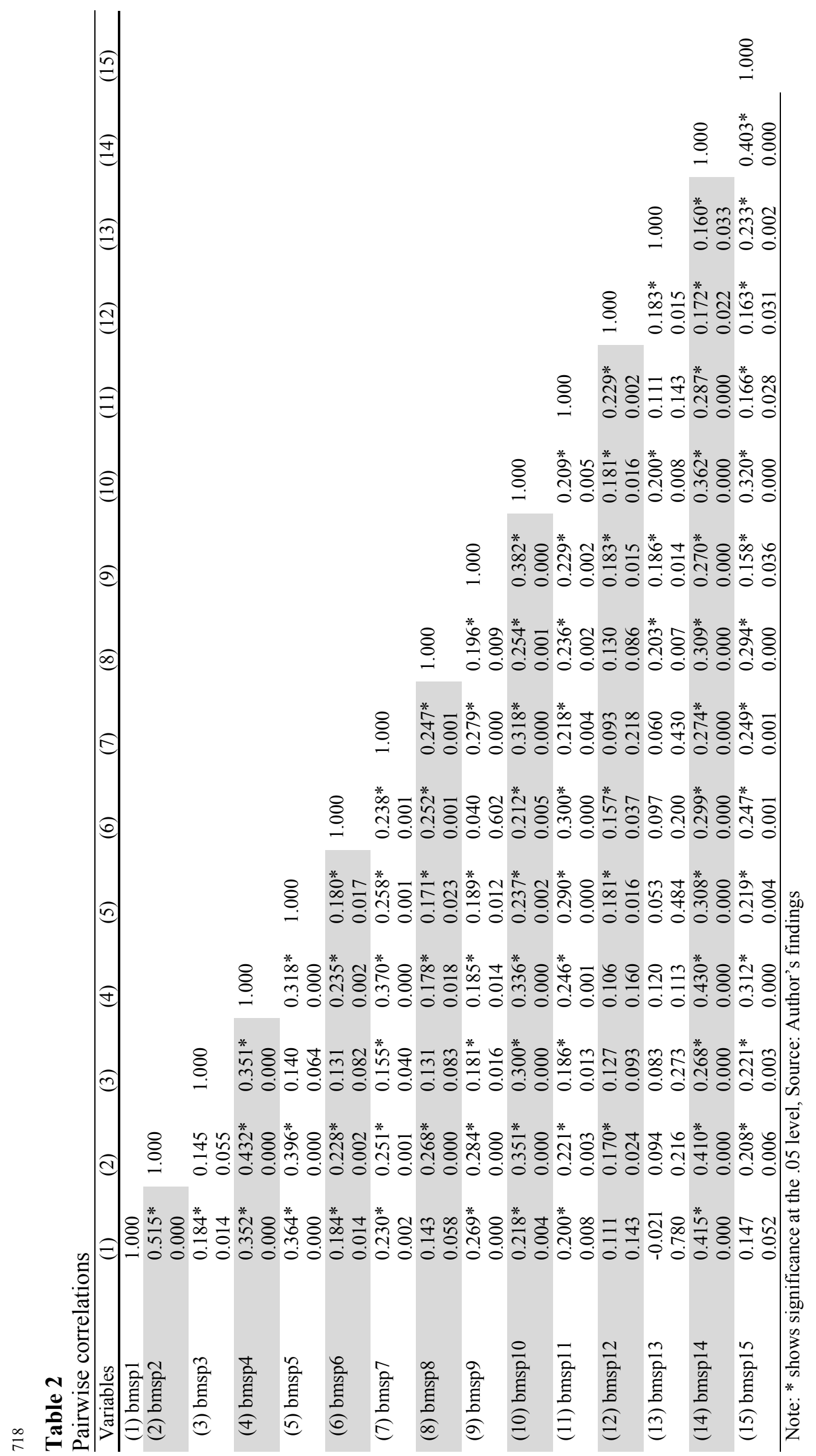


Table 4

Model Specification for external financing of business projects (FM1)

\begin{tabular}{lllllllc}
\hline Source & SS & Df & MS & Number & of & Obs. & $=276$ \\
\hline Model & 98.7058 & 2 & 49.3529 & Prob & $>$ & F & $=0.000$ \\
Residual & 178.726 & 173 & 1.0331 & R-sq. & $=$ & & 0.3558 \\
Total & 277.432 & 175 & 1.58532 & Root & MSE & $=$ & 1.0164 \\
\hline FM1 & Coef. & Std. & Err. & T & P $>$ t & & [95\%Conf. \\
\hline hat & 2.00498 & 0.76487 & 2.62 & 0.01 & 0.49531 & & 3.514647 \\
_hatsq & -0.1538 & 0.11597 & -1.33 & 0.187 & -0.3827 & & 0.0751121 \\
_cons & -1.557 & 1.22522 & -1.27 & 0.205 & -3.9753 & & 0.8612676 \\
\hline
\end{tabular}

Table 5

Adequate staffing of financial staff (FM2)

\begin{tabular}{llllllrr}
\hline Source & SS & Df & MS & Number & of & Obs. & $=276$ \\
\hline Model & 98.475 & 2 & 49.2375 & Prob & $>$ & F & 0.000 \\
Residual & 192.411 & 173 & 1.1122 & R-sq. & = & 0.3385 \\
Total & 290.886 & 175 & 1.66221 & Root & MSE & $=$ & 1.0546 \\
\hline FM2 & Coef. & Std. & Err. & T & P>t & [ \\
\hline hat & 2.90138 & 0.74407 & 3.9 & 0.32 & 1.43276 & 4.370002 \\
hatsq & -0.3027 & 0.21714 & -1.39 & 0.111 & -0.5339 & -0.071487 \\
cons & -2.829 & 1.15226 & -2.46 & 0.015 & -5.1033 & -0.554721 \\
\hline
\end{tabular}

Table 6

Turnover rate of accounting and Finance personnel (FM3)

\begin{tabular}{cccccccc}
\hline Source & SS & Df & MS & Number & of & obs & $=$ \\
\hline Model & 78.7953 & 2 & 39.3976 & Prob & $>$ & F & $=$ \\
Residual & 192.654 & 173 & 1.1136 & R-squared & $=$ & 0.000 \\
Total & 271.449 & 175 & 1.55114 & Root & MSE & $=$ \\
\hline FM3 & Coef. & Std. & Err. & T & P>t & t & 1.0553 \\
\hline hat & 2.1885 & 0.95895 & 2.28 & 0.024 & 0.29575 & 4.081249 \\
hatsq & -0.1849 & 0.14802 & -1.25 & 0.213 & -0.4771 & 0.1072439 \\
cons & -1.8288 & 1.51671 & -1.21 & 0.23 & -4.8224 & 1.164878 \\
\hline
\end{tabular}

Table 7

Development of financial budgets (FM4)

\begin{tabular}{llllllll}
\hline Source & SS & Df & MS & Number & Of & Obs & $=276$ \\
\hline Model & 37.5705 & 2 & 18.7852 & Prob & $>$ & F & $=0.000$ \\
Residual & 262.924 & 173 & 1.51979 & R-squared & = & MSE & $=$ \\
Total & 300.494 & 175 & 1.71711 & Root & P $>$ t & 0.125 \\
\hline FM4 & Coef. & Std. & Err. & T & -2.6905 & $95 \%$ Conf. \\
\hline hat & 1.03379 & 1.88688 & 0.55 & 0.584 & -0.5819 & 4.75805 \\
hatsq & -0.0053 & 0.29214 & -0.02 & 0.986 & -6.0182 & 0.5713593 \\
cons & -0.0531 & 3.02217 & -0.02 & 0.986 & 5.911953 \\
\hline
\end{tabular}

\section{Table 8}

Proper policies for safeguarding physical and financial assets in the business (FM5)

\begin{tabular}{llllllll}
\hline Source & SS & Df & MS & Number & of & obs & $=276$ \\
\hline Model & 132.718 & 2 & 66.3589 & Prob & $>$ & F & $=0.000$ \\
Residual & 179.441 & 173 & 1.03723 & R-squared & - & MSE & $=$ \\
Total & 312.159 & 175 & 1.78377 & Root & P>t & 0.4252 \\
\hline fm5 & Coef. & Std. & Err. & T & -0.1806 & 1.0184 \\
\hline hat & 0.70224 & 0.4473 & 1.57 & 0.118 & -0.1007 & 1.585114 \\
hatsq & 0.05284 & 0.07781 & 0.68 & 0.498 & -0.8435 & 0.2064216 \\
cons & 0.3794 & 0.61957 & 0.61 & 0.541 & 1.602299 \\
\hline
\end{tabular}




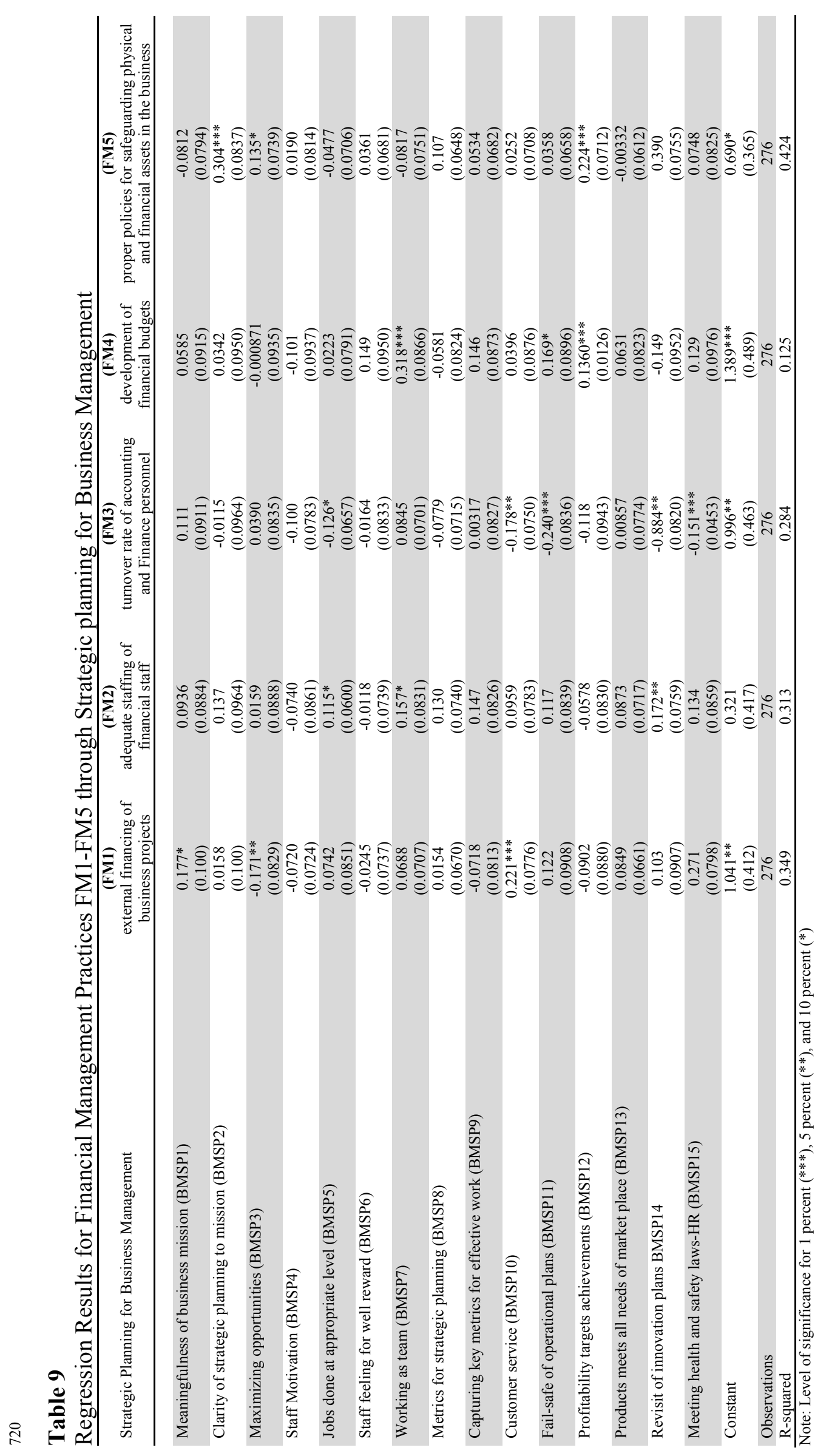


Empirical association between strategic planning for business management and various practices under the title of financial management are presented in Table 9. For explanatory variables, fifteen items are finalized as presented in descriptive and correlational facts, while for FM, five items are finalized. For the first item of BMSP (meaningfulness of business mission), significant \& positive impact of .177 is observed with the standard error of .100. It means that higher significance of business mission can positively impact external financing of the projects as more options of financing could be investigated for the growth of business. For FM5, business missions have a negative but insignificant impact. For BMSP2, clarity of strategic planning to business mission is measured on Likert scale and its impact on all five financial practices is empirically investigated. It is observed that if there is a clarity of mission in the business, it will significantly and positively influence the policy development of safeguarding physical and financial assets in the business. The coefficient of FM5 is .304, significant at 1 percent level, providing the evidence that positive impact on FM5 through BMSP2 is evident. BMSP3 reflects the consideration of maximizing the business opportunities and their impact on FM1 is -.171. It indicates that employees of selected firms agree with the maximization of business opportunities, but they have an adverse effect on FM1. However, for FM5, its impact is .135, meaning that higher opportunities can positively impact safeguarding financial and physical assets of the business.

The factor of staff motivation has no significant association with any of FM dimensions as presented in Table 9. All the coefficients are insignificant but show both positive and negative association with financial management practices. In addition, the factor of doing the appropriate level job is covered under BMSP4, showing significant but positive relationship with adequate staffing for financial staff and negatively significant association with turnover rate of accounting and financial personnel. It means the higher the level job, the more positive influence for more hiring in financial departments and the lower turnover rate by financial staff members. The factor of staff feeling for reward system in their relevant organization has shown insignificant relationship with all dimensions of FM practices. Meanwhile, working as a team in the organization (BMSP7) has demonstrated its significant and positive impact on financial staffing with the coefficient of .157 and standard error .0831. In addition, development of financial budget is positively and significantly impacted by team work in selected firms. Metrics for strategic planning and focus on metrics for effective work have their insignificant impact on all the dimensions of financial management practices. It indicates that there exists no relationship between strategic planning through metrics and financial management behavior of the firm have their no significant relationship. The factor of customer service (BMSP10) predicts significant but positive effect of .221 on external financing for the business projects. For the turnover rate, higher customer service is leading towards low rate of turnover from employees. This relationship is presented through robust coefficient of -.178 with standard error of .0750 . In the meantime, saving business operations from failure means better operational activities, which in return generate adverse results for staff turnover. The coefficient of -.240 accepts adverse relationships.

Higher level of achievements for profitability targets and its influence on financial management practices are also reviewed. The coefficient of .136 indicates that increasing the level of financial performance through earnings is meaningful for the development of financial budgets in business organizations. This trend is similar for the safeguarding of both types of assets (physical and financial), showing the explanatory power of .244, significant at 1 percent. It clarifies that better financial results and their achievements in strategic planning can lead to more security for business assets. Focusing on the products for meeting all the needs of marketplace is found to be insignificantly associated with all dimensions of financial management. Although revisiting innovation plans has significant $\&$ positive association with the staffing of financial staff with the coefficient of .172, and for turnover of the employees, it has a significant but negative influence of -.0884 under full sample. If the business firm is providing better health care and safety facilities to their employees, there is very little chance for the employees to leave the business organization. This notion is accepted as coefficient for FM3 is -.151 through BMSP15. The rest of the indicators are found to be insignificant. Besides, overall value of robust R-square is .349 for FM1, .313 for FM2, .284 for FM3, .125 for FM4 and highest for FM5;.424. All the models are found to be statistically significant. 


\section{Conclusion, Limitations and Future Research}

Strategic planning is accepted as core business process to get long term success in the market. This study has been conducted to empirically evaluate the role of various components of strategic planning under the title of business management in determining financial practices from the context of Kuwait. Overall fifteen items have been identified from the present literature, covering the title of strategic planning. For financial practices, five dimensions have been added in the questionnaire. A sample of 276 respondents was finally accepted because of valid responses and further consideration for empirical facts. It is found that strategic planning factors like meaningfulness of business mission have had a significant but positive influence on external financing of the projects. Clarity of strategic planning to the mission has had a significant but positive impact on safeguarding many types of business assets. However, maximizing the business opportunities were negatively affecting the external financing for the business projects. Besides, working as a team in strategic planning has maintained a significant \& positive influence on development of a financial budget for the business. Meanwhile, customer services were positively influencing external financing of the projects, but negatively affecting the turnover rate of employees. Similar negative \& significant impact was recorded for turnover of personnel. Higher earnings in the business lead to more financial budget and their development along with proper safeguarding of both physical \& financial assets. The factor of jobs accomplished with appropriate levels indicates significant positive impact on staffing financial staff, but negative impact on turnover rate of accounting and finance personnel. If the operational plans are safe from the failure, it indicates a significant but negative impact on turnover of staff members. Higher earnings can provide more opportunity for financial budgets and protection of physical and financial assets in selected business firms.

Findings under the present study contribute to present literature both theoretically and practically. Theoretical implications of the study imply an empirical association between strategic planning and its impact on financial practices in business organizations. These dimensions cover finance department, personnel, development of financial budget, protection of physical and financial assets, etc. Practical implication covers the point that managers and industry analysts responsible for development of strategic planning can consider the stated findings for upcoming tactical forecasting in their relevant firms. However, this study was based on several limitations which can provide some future direction. At first, strategic planning covers the one dimension of overall strategic management process, while ignoring the implementation \& controlling phases which were accepted as significant contributors for success or failure of the business. Future studies can be conducted while adding these attributes of strategic management. Also, sample is limited to the manufacturing firms working in Kuwait. Future studies can be prolonged through addition of trading \& financial sectors too. Financial practices have some other dimensions which can be integrated with strategic planning. For instance, Kudla (1980) highlighted the impact of strategic planning on the return factors of common stock, strategic planning and its interface with finance (Phillips, 2000), finance theory and their implication in strategic management (Bromiley, 1990), role of finance culture in strategic planning (Carr \& Tomkins, 1998), financial coverage in strategic planning (David et al., 2016), and strategic planning in public finance (David et al., 2016; EmenikeKalu \& Obasi, 2016) which can provide new dimensions for upcoming research.

\section{References}

Abor, J., \& Biekpe, N. (2007). Corporate governance, ownership structure and performance of SMEs in Ghana: implications for financing opportunities. Corporate Governance: The international journal of business in society, 7(3), 288-300.

Agarwalla, S. K., Barua, S. K., Jacob, J., \& Varma, J. R. (2015). Financial literacy among working young in urban India. World Development, 67, 101-109.

Albasu, J., \& Nyameh, J. (2017). Relevance of stakeholders theory, organizational identity theory \& social exchange theory to corporate social responsibility \& employees performance in the commercial banks in Nigeria. International Journal of Business, Economics \& Management, 4(5), 95-105. 
Ali, Z., \& Mehreen, A. (2018). Understanding succession planning as a combating strategy for turnover intentions. Journal of Advances in Management Research. https://doi.org/10.1108/JAMR-09-20180076

Ali, A., \& Haseeb, M. (2019). Radio frequency identification (RFID) technology as a strategic tool towards higher performance of supply chain operations in textile and apparel industry of Malaysia. Uncertain Supply Chain Management, 7(2), 215-226.

Alviniussen, A., \& Jankensgard, H. (2015). Enterprise risk budgeting: bringing risk management into the financial planning process.

Anigbogu, U. E., \& Nduka, E. K. (2014). Stock market performance \& economic growth: Evidence from Nigeria employing vector error correction model framework. The Economics \& Finance Letters, 1(9), 90-103.

Anyanwu, J. O., Okoroji, L. I., Ezewoko, O. F., \& Nwaobilor, C. A. (2016). The impact of training \& development on workers performance in Imo State. Global Journal of Social Sciences Studies, 2(2), 51-71.

Berger, A. N., \& Udell, G. F. (2002). Small business credit availability and relationship lending: The importance of bank organisational structure. The economic journal, 112(477), F32-F53.

Bromiley, P. (1990). On the use of finance theory in strategic management. Advances in strategic management, 6, 71-98.

Brooks, R., \& Mukherjee, A. K. (2013). Financial Management: Core Concepts. Pearson.

Bryson, J. M., Crosby, B. C., \& Bryson, J. K. (2009). Understanding strategic planning and the formulation and implementation of strategic plans as a way of knowing: The contributions of actor-network theory. International Public Management Journal, 12(2), 172-207.

Callaway, S. K. (2017). How the principles of the sharing economy can improve organizational performance of the US public school system? International Journal of Public Policy \& Administration Research, 4(1), 1-11.

Camillus, J. C., \& Datta, D. K. (1991). Managing strategic issues in a turbulent environment. Long Range Planning, 24(2), 67-74.

Carr, A. S., \& Smeltzer, L. R. (2000). An empirical study of the relationships among purchasing skills and strategic purchasing, financial performance, and supplier responsiveness. Journal of Supply Chain Management, 36(2), 40-54.

Carr, C., \& Tomkins, C. (1998). Context, culture and the role of the finance function in strategic decisions. A comparative analysis of Britain, Germany, the USA and Japan. Management Accounting Research, 9(2), 213-239.

Carter, H. (1999). Strategic planning reborn. Work Study, 48(2), 46-48.

Cassidy, A. (2016). A practical guide to information systems strategic planning. Auerbach Publications.

Chan, L.-K., \& Wu, M.-L. (2002). Quality function deployment: A literature review. European Journal of Operational Research, 143(3), 463-497.

Charnes, A., Cooper, W. W., \& Miller, M. H. (1959). Application of linear programming to financial budgeting and the costing of funds. The Journal of Business, 32(1), 20-46.

Cordón-Pozo, E., Garcia-Morales, V. J., \& Aragon-Correa, J. A. (2006). Inter-departmental collaboration and new product development success: a study on the collaboration between marketing and R\&D in Spanish high-technology firms. International Journal of Technology Management, 35(1-4), 52-79.

Crowe, T. J., \& Cheng, C.-C. (1996). Using quality function deployment in manufacturing strategic planning. International Journal of Operations \& Production Management, 16(4), 35-48.

Cuijpers, M., Guenter, H., \& Hussinger, K. (2011). Costs and benefits of inter-departmental innovation collaboration. Research Policy, 40(4), 565-575.

Dansoh, A. (2005). Strategic planning practice of construction firms in Ghana. Construction Management and Economics, 23(2), 163-168.

Das, T. (1991). Time: The hidden dimension in strategic planning. Long Range Planning, 24(3), 49-57.

David, F. R., David, M. E., \& David, F. R. (2016). How important is finance coverage in strategic management? International Journal of Management \& Human Resources, 4(1). 
Dayananda, D., Harrison, S., Irons, R., Herbohn, J., \& Rowland, P. (2002). Capital budgeting: financial appraisal of investment projects. Cambridge University Press.

Dudin, M., Kucuri, G., Fedorova, I., Dzusova, S., \& Namitulina, A. (2015). The innovative business model canvas in the system of effective budgeting. Asian Social Science, 11(7), 290-296

EmenikeKalu, O., \& Obasi, R. (2016). Long-run relationship between marketing of bank services \& the performance of deposit money banks in Nigeria. International Journal of Economics, Business \& Management Studies, 3(1), 12-20.

Enz, C. A., \& Siguaw, J. A. (2003). Revisiting the best of the best: Innovations in hotel practice. Cornell Hotel and Restaurant Administration Quarterly, 44(5-6), 115-123.

Fisher, E. A. (2009). Motivation and leadership in social work management: A review of theories and related studies. Administration in Social Work, 33(4), 347-367.

Froot, K. A., \& Stein, J. C. (1998). Risk management, capital budgeting, and capital structure policy for financial institutions: an integrated approach. Journal of financial economics, 47(1), 55-82.

Goodstein, L. D., Pfeiffer, J. W., \& Nolan, T. M. (1986). Applied strategic planning: a new model for organizational growth and vitality. Strategic Planning. University Associates, Inc., San Diego, CA, 2.

Grant, R. M. (2003). Strategic planning in a turbulent environment: Evidence from the oil majors. Strategic Management Journal, 24(6), 491-517.

Grant, R. M. (2016). Contemporary strategy analysis: Text and cases edition. John Wiley \& Sons.

Guilding, C., Lamminmaki, D., \& McManus, L. (2014). Staff turnover costs: In search of accountability. International Journal of Hospitality Management, 36, 231-243.

Haines, S. (2016). The systems thinking approach to strategic planning and management. CRC Press.

Harrison, E. F. (1995). Strategic planning maturities. Management decision, 33(2), 48-55.

Hopkins, D. S. (1981). New-product winners and losers. Research Management, 24(3), 12-17.

Haseeb, M., Abidin, I. S. Z., Hye, Q. M. A., \& Hartani, N. H. (2018). The Impact of Renewable Energy on Economic Well-Being of Malaysia: Fresh Evidence from Auto Regressive Distributed Lag Bound Testing Approach. International Journal of Energy Economics and Policy, 9(1), 269-275.

Howlett, M. (2009). Governance modes, policy regimes and operational plans: A multi-level nested model of policy instrument choice and policy design. Policy Sciences, 42(1), 73-89.

Kahraman, C., Ertay, T., \& Büyüközkan, G. (2006). A fuzzy optimization model for QFD planning process using analytic network approach. European Journal of Operational Research, 171(2), 390-411.

Kaka, A. P. (1994). Contractors' financial budgeting using computer simulation. Taylor \& Francis.

Kaplan, R. S., \& Norton, D. P. (1996). Using the balanced scorecard as a strategic management system. Harvard business review Boston.

Kaplan, R. S., \& Norton, D. P. (2001). Transforming the balanced scorecard from performance measurement to strategic management: Part II. Accounting horizons, 15(2), 147-160.

Kemp, R. L. (2018). Strategic Planning in Local Government: Routledge.

Killen, C. P., Walker, M., \& Hunt, R. A. (2005). Strategic planning using QFD. International Journal of Quality \& Reliability Management, 22(1), 17-29.

King, W. R. (1983). Planning for strategic decision support systems. Long Range Planning, 16(5), 7378.

King, W. R., \& Cleland, D. I. (1978). Strategic planning and policy. Van Nostrand Reinhold Company.

Klemm, M., Sanderson, S., \& Luffman, G. (1991). Mission statements: Selling corporate values to employees. Long Range Planning, 24(3), 73-78.

Kudla, R. J. (1980). The effects of strategic planning on common stock returns. Academy of management Journal, 23(1), 5-20.

Lam, A., \& Lambermont-Ford, J.-P. (2010). Knowledge sharing in organisational contexts: a motivationbased perspective. Journal of Knowledge Management, 14(1), 51-66.

Le, H. L., Vu, K. T., Du, N. K., \& Tran, M. D. (2018). Impact of working capital management on financial performance: The case of Vietnam. International Journal of Applied Economics, Finance \& Accounting, 3(1), 15-20.

Linn, M. (2008). Planning strategically and strategic planning. The Bottom Line, 21(1), 20-23. 
Main, L. (2016). Assessing intangible assets and their value to business: business \& economy. Professional Accountant, 2016(28), 13-15.

Malarvizhi, C. A., Nahar, R., \& Manzoor, S. R. (2018). The strategic performance of Bangladeshi private commercial banks on post implementation relationship marketing. International Journal of Emerging Trends in Social Sciences, 2(1), 28-33.

Maldonado-Guzman, G., Marin-Aguilar, J., \& Garcia-Vidales, M. (2018). Innovation \& performance in Latin-American small family firms. Asian Economic \& Financial Review, 8(7), 1008-1020.

Maroofi, F., Ardalan, A. G., \& Tabarzadi, J. (2017). The Effect of Sales Strategies in the Financial Performance of Insurance Companies. International Journal of Asian Social Science, 7(2), 150-160.

Mayer, C. (1988). New issues in corporate finance. European Economic Review, 32(5), 1167-1183.

Mcdonald, M. (2016). Strategic marketing planning: theory and practice. The marketing book (pp. 108142): Routledge.

McLean, M. (2018). Understanding your economy: Using analysis to guide local strategic planning. Routledge.

Midler, C. (2013). Implementing a low-end disruption strategy through multiproject lineage management. The Logan case. Project Management Journal, 44(5), 24-35.

Mowlaei, M. (2017). The impact of AFT on export performance of selected Asian developing countries. Asian Development Policy Review, 5(4), 253-261.

Phillips, P. A. (2000). The strategic planning/finance interface: does sophistication really matter? Management Decision, 38(8), 541-549.

Phillips, P. A., \& Moutinho, L. (1999). Measuring strategic planning effectiveness in hotels. International Journal of Contemporary Hospitality Management, 11(7), 349-358.

Purnama, C. (2014). Improved performance through empowerment of small industry. Journal of Social Economics Research, 1(4), 72-86.

Quinlan, K. M., \& Åkerlind, G. S. (2000). Factors affecting departmental peer collaboration for faculty development: Two cases in context. Higher Education, 40(1), 23-52.

Rashid, A. (2014). Firm external financing decisions: explaining the role of risks. Managerial Finance, 40(1), 97-116.

Reese, C. D. (2008). Occupational health and safety management: a practical approach. CRC press.

Ruhanen, L. (2007). Destination competitiveness: meeting sustainability objectives through strategic planning and visioning Advances in modern tourism research (pp. 133-151): Springer.

Santhi, N. S., \& Gurunathan, K. B. (2014). Fama-French three factors model in Indian mutual fund market. Asian Journal of Economics \& Empirical Research, 1(1), 1-5.

Sayer, J., LeBlanc, D., Bogard, S., Funkhouser, D., Bao, S., Buonarosa, M. L., \& Blankespoor, A. (2011). Integrated vehicle-based safety systems field operational test final program report.

Slawinski, N., \& Bansal, P. (2015). Short on time: Intertemporal tensions in business sustainability. Organization Science, 26(2), 531-549.

Sokol, R. (1992). Simplifying strategic planning. Management Decision, 30(7).

Stein, J. C. (1997). Internal capital markets and the competition for corporate resources. The Journal of Finance, 52(1), 111-133.

Steiner, G. A. (2010). Strategic planning. Simon and Schuster.

Suryanto, T., Haseeb, M., \& Hartani, N. H. (2018). The correlates of developing green supply chain management practices: Firms level analysis in Malaysia. International Journal of Supply Chain Management, 7(5), 316.

Tan, K. C., \& Shen, X.-X. (2000). Integrating Kano's model in the planning matrix of quality function deployment. Total Quality Management, 11(8), 1141-1151.

Tikhomirov, B. I., \& Frenkel, A. A. (2017). On unified socio-economic policy and strategic planning. Economic Policy, 4, 82-117.

Tsai, C.-Y., Lo, C.-C., \& Chang, A. C. (2003). Using fuzzy QFD to enhance manufacturing strategic planning. Journal of the Chinese Institute of Industrial Engineers, 20(1), 33-41.

Utterback, J. (1994). Mastering the dynamics of innovation: How companies can seize opportunities in the face of technological change. 
Wolf, C., \& Floyd, S. W. (2017). Strategic planning research: Toward a theory-driven agenda. Journal of Management, 43(6), 1754-1788.

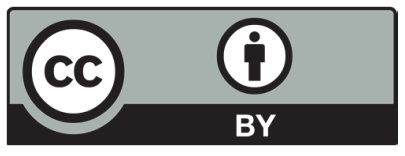

C 2019 by the authors; licensee Growing Science, Canada. This is an open access article distributed under the terms and conditions of the Creative Commons Attribution (CCBY) license (http://creativecommons.org/licenses/by/4.0/). 